\title{
茶花除雄の一方法について*
}

農林省東海近㖪農業試験場䒩業部 増 田清志

\section{A New Castration Method of the Tea Flower's}

\author{
By Kiyoshi Masuda
}

\section{1.はしがき}

これまで茶花の除雄方法としては, 開花前日に营の花 升を上部から開き，花紶をピンセットでつまんで䒺を取 り除く方法汃慣行的婂行われてきた。しかしこの力法に

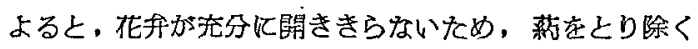

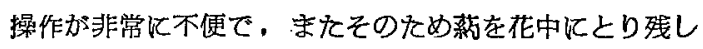
たり，医し溳して花粉を散らすてとなどが多い。そのた めてれをてい忯に行䅂うとすると非常に時間がかか る。これを簡便に行うために，茶街は自家不稳性が高い ので，無除雄のまま交配を行うことも考沉られる。しか

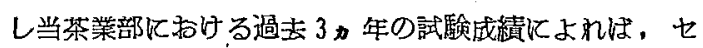
ルフの場合最高 $17 \%$ ，最低 $3.2 \%$ の結果率を示している から，交配を撖密に行うためには，やはり路雄が必要で ある。それで证来の除雄方法を簡易化するため次の方 法を試みたとてろ、その成績がよかつたので、こてにそ の結果を報告する。本交にさきだち御指導を賜かつた，

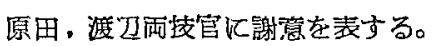

\section{2. 試験方法と結果}

新しい路雄方法として次の方法を試みた。ます交配用

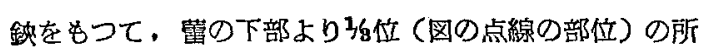

蕾の横断面

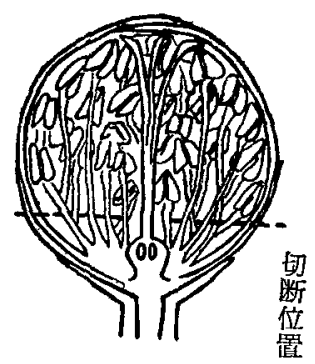
亿切れ昌を入れ、その切 れ目に鍁を入れて花桂に 届かない程度の梁さにま わりから切りこんで、花 弁と花紜を切り離し、さ らに残つた一部の雄票は ピンセットで花絲をつま んで完全により除く。 S 55 と $\mathrm{s} 6$ の両品種につ き各区50化ずつ用いて。 この方法と従来の方法との比較を行つたとてろ，その結 果は次のと和りであつた。

1. 一花当り除雄所要時間

在来法49秘㳔して新方法は17秒を要した。

2. 除雄花における莸並びに花粉の残存
相当ていねいに除雄を行つても。除雄花中に䕀または 花粉が残荪している場合があるので，\$55を用いてれら の残存数について調查した。第 1 表のように在来法では 残存花数が非常に多かつた。

第 1 表 除雄後の䒺または花粉の残存

\begin{tabular}{|c|c|c|c|}
\hline 然理方法 & 調查花数 & 蒜残存花数 & $\begin{array}{l}\text { 花数のみ } \\
\text { 残存花数 }\end{array}$ \\
\hline 新 方 法 & 30 & 1 & 1 \\
\hline 在 来法 & 30 & 7 & 4 \\
\hline
\end{tabular}

3, 結 果率

S 19 を授将花比用い交配を行つたところ：その成績は

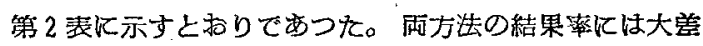
は多いよう炕思われる。

\begin{tabular}{|c|c|c|c|c|c|}
\hline \multicolumn{2}{|c|}{ 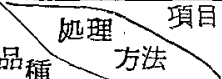 } & 好理花数 & 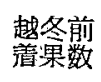 & $\begin{array}{l}\text { 最終 } \\
\text { 結果数 }\end{array}$ & 結果率 \\
\hline \multirow{2}{*}{ s 55} & 新方法 & 50 & 40 & 17 & $34^{\%}$ \\
\hline & 在来法 & 50 & 32 & 12 & 24 \\
\hline \multirow{2}{*}{ s 6} & 新方法 & 50 & 39 & 2 & 4 \\
\hline & 在来法 & 50 & 45 & 2 & 4 \\
\hline
\end{tabular}

筫考 : \$6 は過去の交配結果率も5.3\%で非常に低い。

\section{3. 摘要}

交配鋏を用いる新方法によれば、除雄時䦭はきわめて 短く，且つ操作がきわめて容易であつた。また花弁を切 り除くことは別に結果率には影響しない8のと思われ た。ことに在来法では蒜や花㸮を花中に見残すことが多 いので, 完全涂雄し得る点でも新方法のほうが優つて

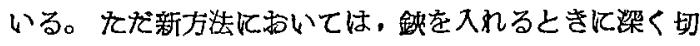
り過ぎて、花杜を晿め好よ注意を要する。

*葉業技街研究 No.12，6７（1955）より転载 


\section{Summary}

The efficiency and the results were examined about the newly improved castration method of the tea flowers with scissors. The new method showed better results than the castomary method with pincette.

(Jan. 8, 1955)

\title{
茶樹に対するビニル被覆の効果について*
}

\author{
農林省東海近畿農業試験場茶業部青野 英也・高橋 恒二
}

\section{The Effect of Vinyl Cover on the Tea Plant}

\author{
By Hideya AONO and Tsuneji TAKAHASHI
}

\section{1. 腥 言}

最近農業用ビニルフィルムの園芸方面に対する利用 は，育苗その他において好成績を収め。水稻育苗にもそ

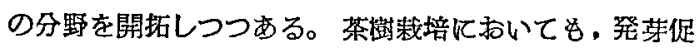
進, 凍霜害防除，秋冬期纪わける育苗等，利用可能亡考 えられる面が少くない。殊に荣における価格のはげしい 変動は、ビニル被琾によるかずかの日数の発芽促進によ つて，その製品の価值に著しい相違をきえし，価格は上

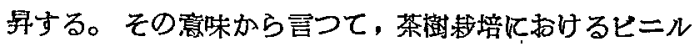
利用の効果をあげ得る最も有望な方洗として，発芽促進 効果を検討するため，1954年 3月〜 4 月にわたつて色種 と透明度の異なるどニルフィルムを使用して，その発穿 促進効果, 及び茶㷊の化学成分に及ぼす影響について試 験し、併せてその微気象に及ほす影響について試験し た。その結果若干の知見を得たのでててに報告する。本 試験に際して助力を得た研究空各位の労に梁謝し，化学 分析に御協力を得た化学研究空諸蜸に謝當を表する。

\section{2. 試 踰 の 概 要}

本試験に供試した品種はやぶきた (中生種), 印雑131 (早生種)で焉り，広さ 0.83 坪のビニルハウスを作り。 （所要経費，木枠代1400円，ビニルフィルム代約2300円， 計約3700円)，やぶをたは線色梨地，青色透明，緑色 透明，無色透明の 4 色を，印雑 131 には白色梨地を 3 月 1 日飞被覆し、以後日中高温時に注空を開いて空温を調 節し，4月8 日摘採制造供した。室内の温度調查は空 内の地下 $30 \mathrm{~cm}, 20 \mathrm{~cm}, 10 \mathrm{~cm}, 5 \mathrm{~cm}$, 地表面, 地上 $15 \mathrm{~cm}$ (茶株面) $, 50 \mathrm{~cm}, 100 \mathrm{~cm}, 150 \mathrm{~cm}$ 地点にそれぞれ曲管 地中寒爱针及び抖 状寒䁔計を設け，3月1日より4月 10日まで，9時，15㭙に逨日観測し，また各室內にオー グスト乾湿球湿度計を設置して湿度を併測し、3月10日
（曒天より雨天に移行する場合）欧 3 月23日（晴天の場

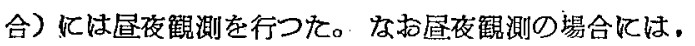

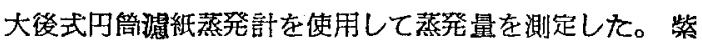
外線量は中央気象合式紫外計を使用して測定した。乙の

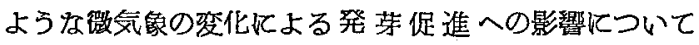
は, 伸育量等の生育相への影響，室内比ける炭素同化

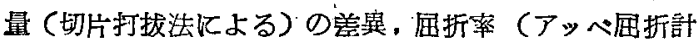
による)の变化等について検討を加えた。また化学成分

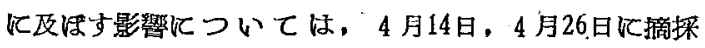
し. 常法により分析した。

\section{3. 試験結果及び考案}

\section{1. 被麗期間の気象状態}

被覆期間中の 9 時及び15時に，露天と各ビニルハウス 内の気温, 土中温度, 関係湿度を觀測した結果は, 第1諘 及び第 2 表(旬間の平均温湿度)のでとくである。第 1 表 の9時の㗌内温度についてみると、露天に比へで・ビ

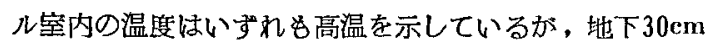
の温度は：3 月下旬湾露天と無色透明ハウスとの間に。 $1.9^{\circ} \mathrm{C}$ の最大温度羑を示しており，地表面に近づく従 つてその瑟は大きくなつている。このようにどニル被蕧 による土中温度の上昇は，地表面近く張り出してきてい る茶樹の吸收根か， 2 月下旬 3 月上旬になつて, 気温 の上昇とともに活動を始める作用を更に助長し、萠芽を 促進させるものとして注目されよう。更に地表面以上の 室内温度では，その羑梖しく現われている。またてれ らの温度盖について，ヒニルフィルムの透明度, 色種に よる美を検討してみると、梨地（白色梨地，緣色梨地） と透明色（緑色透明，青色透明，無色透明）とでは，透 明色の方が高温の傾向があり，殊敒無色透明の温度は， いずれの観測地点に抬いても常に高くなつている。色種

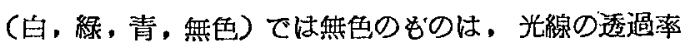

*茶業技術研究 No.12, 7 12 (1955) より転載。 